\title{
Impact of Curriculum Integration Related to Spiritual Care on Nurse Competence in Providing Spiritual Nursing Care
}

\author{
$1^{\text {st }}$ PS Aisyah \\ Nursing study program \\ STIKes 'Aisyiyah Bandung \\ Bandung, Indonesia \\ nursepops02@gmail.com
}

\author{
$2^{\text {nd }}$ Rosyanti \\ Nursing study program \\ STIKes 'Aisyiyah Bandung \\ Bandung, Indonesia
}

\author{
$3^{\text {rd }} \mathrm{N}$ Rohmah \\ Nursing study program \\ STIKes 'Aisyiyah Bandung \\ Bandung, Indonesia
}

\begin{abstract}
The impact of the ongoing integration of spiritual nursing care in the curriculum on nurses' competencies in providing spiritual care while in the workforce has not been studied. STIKes Aisyiyah Bandung as one of the health colleges in West Java that has integrated spiritual nursing care into the curriculum of the Nursing Diploma III study program. The purpose of this study was to identify the competencies of nurses who graduated from Stikes Aisyiyah Bandung, especially in providing spiritual care after becoming a nurse at a hospital. Spiritual nursing care is caring activities that improve people spiritual wellbeing and helping people to endure and trascend the hard situation. A Comparative study was conducted in June 2019. Using a purposive sampling, 224224 samples were selected from nurses working in the inpatient ward $A L$ IHSAN Hospital West Java Province and Al Islam Hospital Bandung. Based on the results of the Mann Whitney test, there were differences in the scale of competence of nurses who graduated from STIKes' Aisyiyah Bandung and nurses who graduated from non-SAB with a significance value of $0.001(\alpha<0.005)$. The difference between the Spiritual Care Competence Scale average scores of the competencies of Stikes' Aisyiyah Bandung graduated $(73 \pm 11.60)$ and nonSAB graduated $(66 \pm 13.6)$. The integration of spiritual care studies in the nursing higher education curriculum has a good effect on the competence of nurses in providing spiritual nursing care services.
\end{abstract}

\section{Keywords-Curricullum, Spiritual Care, Nursing}

\section{INTRODUCTION}

Nursing services must ensure the holistic of nursing care continuously and consistently. Holistic nurses recognizes the patients are biological, social, emotional, and spiritual beings[1] Some of the literature revealed that implementation of spirituality in nursing practice are still lacking [2]-[5]. The application of spiritual care in nursing services is still lacking mainly due to lack of knowledge or differences in understanding of spirituality among nurses themselves, time constraints, as well as religious and social differences between patients and health professionals [2].
Spiritual care as that service which recognizes and responds the spirit of life when faced with trauma, limited threat illness or grief include the need for meaning life Spiritual care activities include assisting patients to make good existential choices in their present situation, helping people to endure and trancend the hard situation, improving interpersonal relationships and relationship between a person and God. The purpose of this service is restoring a person to condition of spiritual wholeness [2], [6]. Utilization of the spiritual aspects that exist in the individual becomes an important part to help patients in difficult situations both life-threatening and life-limiting [7]. Fulfilling spiritual needs is as important as fulfilling physical needs while the patient is treated in the hospital.

The Provision of spiritual services to patients is very beneficial to improve the quality of patients' health. Fulfilling spiritual needs can help patients in reducing feelings of depression during illness and providing a feeling of security for patients [8]. Health services that do not pay attention to spiritual care tend to provide negative experiences to patients during the treatment period [3]. It is therefore crucial that nurses increase their role in providing spiritual care.

The goal of spiritual nursing care is to increase the patient's spiritual well-being, increase psychological adaptation of patients, increase patient satisfaction, increase spiritual awareness among patients and increase job satisfaction for health professionals[8]. The role of nurses here is not only to provide spiritual assistance for patients, but nurses must be able to carry out advocacy functions to patients in defending the client's right to be able to make decisions for themselves during treatment [9].The competence of nurse in providing spiritual care is greatly supported to journey of spiritual service in nursing.

Nurse competence is part of cultural competency that be developed in providing spiritual care. Diverse individual spiritual beliefs are private sentimental areas and have 
culture influenced. The Canada Nurse Association explained that a nurse who is said to be competent in providing spiritual care is who has sensitivity and respect for diverse spiritual beliefs, supports the selection of spiritual activities following the wishes and focuses on fulfilling spiritual needs[10]. Nurse competence in providing spiritual care is used as an indicator in assessing the performance of the health service system. Therefore, it is essential that nurses' competencies in spiritual care are regularly evaluated in order to improve service quality.

Several studies related to the evaluation of spiritual care competencies showed that student nurses' perceptions tend to be more positive towards the provision of spiritual nursing care compared to nurses in service [2], [3], [10]. The limitations of the application of spiritual care can be due to limited knowledge, are not exposed to training or routine activities that are limited to activities to help patients in practicing worship, as well as an unsupportive service system[2]. This showed the unsustainability of spiritual care application during the education period with the world of work.

STIKes Aisyiyah Bandung is the only provider of nursing higher education in West Java that integrates Islamic spiritual care into the curriculum. Islam spiritual nursing care is an institutional curriculum that has been developed since 2009 as a typical feature of the study program's graduates. This AKSI (Asuhan Keperawatan Spiritual Islam) has received a certificate of IPR (Intellectual Property Rights) by the Ministry of Law and Human Rights, AKSI is a nursing care service to clients in an effort to meet basic spiritual needs comprehensively including assessment, planning, implementation and evaluation. Excellence of graduates in providing Islamic spiritual services is a force that supports the acceleration of uptake of graduates in the world of work, especially hospitals based on Islam.

Al-Ihsan and Al Islam is both of hospital West Java provincial hospital that conducts Islamic-based health services. They have accepted most graduates nurse from STIKes 'Aisyiyah Bandung. Nurses are the most human resources in the hospital environment, so it plays an important role in achieving the vision and mission in the hospital. Nurses' performance appraisal is always carried out on an ongoing basis but an assessment of spiritual care competencies has never been done. There is an unsustainability between the application of spiritual care while being a student nurse and after being a nurse in some literature. Evaluation of nurses' competency in applying spiritual care is very important to be measured in order to improve holistic nursing services. This study is to compare the spiritual care competency of the Nurses graduated from STikes Aisyiyah Bandung to the nurses graduated from other colleges

\section{METHOD}

The study design used comparative descriptive research. The study was conducted in June 2019 Al-Ihsan Hospital District West Java Province and Al islam Hospital Bandung. The number of samples used in the study was 224 respondents. The sample distribution was divided into two groups from 112 graduated from STIkes Aisyiyah Bandung $(\mathrm{SAB})$ and 112 did not graduate from SAB. The taking sample technique with purposive sampling. Inclution criteria is nurses from adult inpatient ward and nurse graduated above years 2012. Exclution criteria is nurses from pediatric inpatient ward. The research variable was spiritual care competence. Spiritual care competence is the nurse's ability to provide spiritual care to patients. The instrument used for data collection was Spiritual Scale Competence adopted from Leuween et al [10]-[12] with a Croncbach alpha reliability value of $0.56-0.82$. To guarantee the validity of the measuring instrument, the researchers conducted content validity tests related to the translation of instruments by language experts and nurse experts in the field of Muslim Spiritual Nursing Care. Instruments that have been translated into Indonesian by language experts are then re-translated into English to obtain the same meaning. The instrument will be tested for the validity of the group of nurses at Rumah Sakit Muhammadiyah Bandung as many as 30 nurses with the reliability test results of 0.957 and the results of the validity test $(>0.547-0.859)$

Analysis data used univariate analysis with frequency distribution and bivariate analysis used mann whitney because the distribution of data groups was not normal with the results of the normality test using shapirowilk with a significance value of 0.026 in groups 1 and 0.103 in groups 2. Ethics approval in this study was obtained from the Research Ethics Commission - Al Islam Bandung Hospital. Respondents can fill out a questionnaire and can become Research subjects after they read and filled out informed consent in this study.

\section{RESULT}

\section{A. Respondents Characteristic}

The frequency distribution of respondents' characteristic results according to sex roles, education, training experience and years of work is presented in table I below.

TABLE I. CHARACTERISTICS OF INPATIENT NURSES (N 224 NURSES)

\begin{tabular}{|l|c|c|c|c|}
\hline \multirow{2}{*}{ Demographic Characteristics } & \multicolumn{2}{|c|}{ Graduated from SAB } & \multicolumn{2}{c|}{ Not Graduated from SAB } \\
\cline { 2 - 5 } & $(\mathrm{N}=112)$ & $\%$ & $(\mathrm{~N}=112)$ & $\%$ \\
\hline Gender & & & & \\
Female & 68 & 60.7 & 63 & 56.3 \\
Male & 44 & 39.3 & 49 & 43.7 \\
\hline Training experience & & & & \\
Ever & 98 & 87,5 & 96 & 85,7 \\
Has never been & 14 & 12.5 & 16 & 14,3 \\
\hline Education & 112 & 100 & 105 & 93.7 \\
D3 & & & & \\
\hline
\end{tabular}




\begin{tabular}{|l|c|c|c|c|}
\hline \multirow{2}{*}{ Demographic Characteristics } & \multicolumn{2}{|c|}{ Graduated from SAB } & \multicolumn{2}{c|}{ Not Graduated from SAB } \\
\cline { 2 - 5 } & $(\mathrm{N}=112)$ & $\%$ & $(\mathrm{~N}=112)$ & $\%$ \\
\hline Ners & 0 & 0 & 7 & 7.7 \\
\hline Years of work & 55 & 49,1 & 53 & 47,3 \\
Less of 3 years & 57 & 50,9 & 59 & 52,7 \\
Above of 3 years & & & & \\
Spiritual Competition Level & 35 & 10,3 & 32 & 28,6 \\
Good & 77 & 89,7 & 65 & 58,1 \\
Enough & 0 & & 15 & 13,3 \\
Less &
\end{tabular}

\section{B. Spiritual Scale Competence}

TABLE II. SPIRITUAL CARE COMPETENCE SCALE OF NURSES

\begin{tabular}{|l|c|c|c|c|r|c|}
\hline $\begin{array}{l}\text { Nurse } \\
\text { Group }\end{array}$ & Mean & Median & Max value & $\begin{array}{l}\text { Min } \\
\text { value }\end{array}$ & SD & P value \\
\hline Graduated from SAB (N & 72.4 & 73 & 41 & 91 & 11.6 & \multirow{2}{*}{.001} \\
\hline Not Graduated from SAB & 62.8 & 66 & 37 & 85 & 13.2 & \\
\hline
\end{tabular}

Based on the results of the mann whitney test showed h0 failed to reject with a significance value of $0.001(\alpha$ $<0.005)$. This showed that there were differences in nurse competence in providing spiritual nursing care to patients. Nurse's spiritual competence was at the level of competence sufficient to the group of nurses who graduated from STIkes Aisyiyah Bandung or those who did not graduate from SAB Bandung. Even though competencies at the same level can be seen in table.III, the differences in competency in the two groups of nurses which the competency of spiritual nursing review and implementation of nurses graduating from STIKes Aisyiyah bandung tended to be better than non-SAB graduates.

TABLE III. OVERVIEW OF NURSE COMPETENCIES BASED ON SUB COMPETENCIES

\begin{tabular}{|l|c|c|}
\hline \multicolumn{1}{|c|}{ Domain aspects of competency } & \multicolumn{2}{|c|}{ Graduate } \\
\cline { 2 - 3 } & $\mathrm{SAB}$ & $\mathrm{Non} \mathrm{SAB}$ \\
\hline Attitudes towards the spiritual needs of patients & 4.31 & 4.01 \\
\hline Communication & 4 & 4.03 \\
\hline Study and implementation of spiritual nursing actions & 4.1 & 3.9 \\
\hline Referral ability & 3.6 & 3.74 \\
\hline Personal support and patient counselling & 3.8 & 3.92 \\
\hline Professionalism and quality assurance of spiritual care & 3.3 & 3.47 \\
\hline
\end{tabular}

\section{DISCUSSION}

The results of the study showed that the competence of nurses participating in the study had a sufficient or moderate level of nursing care competency level in the group that had received spiritual care curriculum during their education or not. Competency was a person's self quality that led to effective performance results[11]. Nurse's competency that was at a moderate level showed that nurses' performance in providing spiritual nursing care was good enough that it only needs to be optimized.

Nurses in the inpatient room at Al- Ihsan Bandung and $\mathrm{Al}$ islam Bandung Hospital has very good competency in the aspect of competence of nurses' attitudes towards the spiritual needs of patients and communication competencies. The high awareness of nurses towards the spiritual will support the successfulness of providing spiritual nursing care. The better the spirituality of a nurse will be more sensitive to the fulfillment of the spiritual needs of patients[9], [13]. The existence of a hospital policy that has a vision of working according to the foundation of worship to Allah and all Muslim respondents makes all nurses have the same personal aspect domain competence without differentiating the origin of the tertiary institution.

The clinical order environment can be a source of learning for nurses in developing spiritual nursing care. Nurses who have no experience in providing spiritual care during education can model the model of spiritual nursing care for senior nurses during their work.[9], [10] This does not mean that the integration of spiritual service curriculum is not important. The integration of the spiritual curriculum during the education period would assist nurses in clarifying the complexity of the concept of spirituality; raising awareness of personal spirituality, facilitating the provision of care measures for spiritual care; and internalizing attitudes deeply the importance of fulfilling spiritual needs for patients[3], [10]. The results showed that aspects of the competence of the assessment and implementation of spiritual nursing actions, attitude competencies and communication competencies in nurses graduated from STIkes Aisyiyah Bandung had higher scores than nurses who did not experience the process of learning spiritual services during the education period.

The provision of spiritual nursing care is not only sufficiently supported by the high awareness of nurses on aspects of spirituality but there needs to be a quality relationship between the quality of nurses and patients' performance[8]. High workload, unbalanced ratio of nurses and patients, nurse work arrangements that focus on the demand for doctors and the large number of tasks outside of nursing actions have resulted in ineffective relationships between nurses and patients in spiritual nursing care [2], [10]. This is in line with the characteristics of the inpatient rooms which are used as research sites that have a high workload and more assignments to the fulfillment of 
physical needs that are in line with the doctor's request so that the nursing care services performed are limited to the fulfillment of the patient's practical worship and spiritual assessment. This is in line with research that nurses are less competent in the aspects of developing the quality and quality of nursing care services.

Referral aspect competence, spiritual service quality development and counseling support have not been optimal because this competency is related to the division of nurses' competencies at the level of intermediate experts and nurses in managing inter-professional nursing care [10], [13]. Association f Nurse Indonesia explained that the competence of ahli madya nurses in referring activities is referring patients to nurses with the title ners, in contrast to the competencies of the nurses with the title ners must be able to collaborate with peer teams and other health workers.[14] The nurses who participated in the study were all graduates of SAB diploma III nursing.

STikes Aisyiyah Bandung has integrated spiritual care in the curriculum both at the level of the intermediate expert study program and in the nurses program in the form of courses on Islamic spiritual nursing care (AKSI). Islamic spiritual nursing care is providing nursing services to Islamic-oriented patients, based on the approach of the nursing process including assessment, nursing diagnoses, interventions, implementation and evaluation [15], [16] AKSM learning achievements in undergraduate study programs were added to the aspects of managing patients with special needs in an interdisciplinary manner, counseling skills and using research results that support the development of interventions in meeting spiritual needs. The development of the quality of spiritual care services that have been developed at STIKes' Aisyiyah Bandung such as Spiritual Emotional freedom Technique (SEFT) implementation, Al Quran therapy, and bibliotherapy.

The difference in competence of ahli madya nurses and nurses with the title ners in providing spiritual nursing care makes it necessary to have an intermediate expert competency improvement program after becoming employees in the form of training. Increasing spiritual intelligence in the guidance program for nurses must be constantly carried out. This is in line with Groot et al [17] that spiritual intelligence will increase the clinical competence of a nurse especially in spiritual nursing care services. In an effort to improve the competence of developing professionalism and quality of nursing in spiritual nursing care, a nursing service system can be applied that refers to the standards of syariah hospital services. The development of service quality by applying the results of evidence-based research is one form of implementation of hospital accreditation standards.

\section{CONCLUSION}

The research findings showed that there are differences in the level of spiritual care competence between nursing graduates who undergo the spiritual care curriculum during the education period and nurses who have no experience of spiritual service learning. Limitations of the number of study samples are part of the limitations of this study so that further research needs to be done with a larger number of samples and explore factors that are more dominant on the competence of nurses in providing spiritual nursing care.

\section{ACKNOWLEDGMENT}

We would like to thank to all who have assisted in the implementation process until the completion of this research, to Sekolah Tinggi Ilmu Kesehatan 'Aisyiyah Bandung as the funder of this research. We also thank the Al Ihsan Hospital District West Java and Al Islam Hospital Bandung for providing opportunities and assisting us in data collection. Finally, we thank all parties and colleagues at STIKes 'Aisyiyah Bandung for their support and spirit for make better.

\section{REFERENCES}

[1] V. Zamanzadeh, M. Jasemi, and F. Taleghani, "Effective Factors in Providing Holistic Care: A Qualitative Study," Indian J. Palliat. Care, vol. 21, no. 2, pp. 214-224, 2015.

[2] M. J. Balboni et al., "Nurse and physician barriers to spiritual care provision at the end of life," J. Pain Symptom Manage., vol. 48, no. 3, pp. 400-410, 2014.

[3] B. S. Gallison, Y. Xu, C. Y. Jurgens, and S. M. Boyle, "Acute care nurses spiritual care practices," J. Holist. Nurs., vol. 31, no. 2, pp. 95-103, 2013.

[4] I. Papathanasiou, "Holistic Nursing Care: Theories and Perspectives," Am. J. Nurs. Sci., vol. 2, no. 1, p. 1, 2013.

[5] D. Creedy and L. H. Tiew, "Integration of spirituality in nursing practice: A literature review," Singapore Nurs. J., vol. 37, no. 1, pp. $15-21,2010$.

[6] M. Vermandere, J. De Lepeleire, L. Smeets, K. Hannes, and W. Van Mechelen, "Spirituality in general practice:," no. November, pp. 749-760, 2011.

[7] R. Sawatzky and B. Pesut, "Attributes of spiritual care in nursing practice,” J. Holist. Nurs., vol. 23, no. 1, pp. 19-33, 2005.

[8] F. Timmins and S. Caldeira, "Understanding spirituality and spiritual care in nursing," Nurs. Stand., vol. 31, no. 22, pp. 5057, 2017.

[9] L. Ross et al., "Nursing and midwifery students' perceptions of spirituality, spiritual care, and spiritual care competency: A prospective, longitudinal, correlational European study," Nurse Educ. Today, vol. 67, no. August, pp. 64-71, 2018.

[10] M. Adib-Hajbaghery, S. Zehtabchi, and I. A. Fini, "Iranian nurses' professional competence in spiritual care in 2014," Nurs. Ethics, vol. 24, no. 4, pp. 462-473, 2017.

[11] S. Daghan, A. Kalkim, and T. Sağkal Midilli, "Psychometric Evaluation of the Turkish Form of the Spiritual Care Competence Scale," J. Relig. Health, vol. 58, no. 1, pp. 14-27, 2019.

[12] D. R. Hodge, "The Spiritual Competence Scale: A New Instrument for Assessing Spiritual Competence at the Programmatic Level," Res. Soc. Work Pract., vol. 17, no. 2, pp. 287-294, 2007.

[13] L. Ross et al., "Factors contributing to student nurses'/midwives' perceived competency in spiritual care," Nurse Educ. Today, vol. 36, pp. 445-451, 2016.

[14] Bidang Organisasi PP- and PPNI, "Standar Praktik Persatuan Perawat Nasional Indonesia (PPNI)," Ppni, no. 15, pp. 1-65, 2010.

[15] A. Yusuf, M. F. Iswari, H. E. Nihayati, and F. Okviasanti, "Kebutuhan Spiritual Konsep Dan Aplikasi Dalam Keperawatan," penerbit Mitra Wacana Media, 2016.

[16] I. Puspita, "Aplikasi asuhan keperawatan spiritual muslim," $J$. Keperawatan Univ. Padjajaran, vol. 11, no. Xx, pp. 60-69, 2009.

[17] M. Groot et al., "Spiritual care by nurses in curative cancer care: Protocol for a national, multicentre, mixed method study," J. Adv. Nurs., vol. 73, no. 9, pp. 2201-2207, 2017. 